\title{
Desain meja dan kursi sistem modular berbasis active learning untuk siswa sekolah dasar
}

\author{
Achmad Zainudin, ${ }^{1 *}$ Rahmanu Widayat, ${ }^{1}$ Agus Purwantoro ${ }^{1}$ \\ ${ }^{1}$ Program Studi Magister Seni Rupa, Program Pascasarjana Universitas Sebelas Maret, Indonesia
}

\begin{abstract}
Improving learning quality of elementary school in Indonesia can be conducted in many ways. One of them is repairing tables and chairs in accordance with the development of learning method. Nowadays, active learning is one method of learning proven to be effective in improving learning quality. Many ways have been attemped to realize active learning, starting from curriculum improvement to study time at school. Unfortunately, the government forgets one thing which is not less important, namely tables and chairs used by students everyday. This research intends to provide ideas to the concerned party on how to repair elementary school tables and chairs compatible with active learning method by using modular concept. The research method used in this research is descriptive qualitative. The location of this research is Kedung District, Jepara Regency, Central Java. Samples selected are 3 elementary schools at this district. The study object is the design of tables and chairs used for active learning. Data collection technique is library study, observation and interview. The validity of the data collection is tested by triangulation technique. Research result shows that tables and chairs of the three sixth grade elementaryschols are not representative for active learning. Generally, the tables and chairs are difficult to use in active learning. Tables and chairs using modular design concept fit into $V$ or $U$ cluster/ group and also more ergonomi, functional, easy to move and support active learning.
\end{abstract}

Key words: design, elementary school table-chair, active learning, modular concept

\begin{abstract}
Abstrak
Peningkatan kualitas pendidikan sekolah dasar Indonesia dapat ditempuh dengan berbagai cara. Salah satu yang dapat diupayakan adalah dengan melakukan perbaikan meja kursi sesuai dengan perkembangan metode mengajar. Saat ini, active learning terbukti merupakan metode belajar-mengajar yang efektif meningkatkan kualitas pendidikan. Berbagai hal telah diupayakan dalam rangka mewujudkan active learning, mulai dari perbaikan kurikulum hingga jam belajar di sekolah. Sayangnya pemerintah melupakan satu hal yang tidak kalah penting untuk diperhatikan, ialah meja kursi yang dipakai siswa untuk belajar sehari-hari. Penelitian ini bermaksud memberikan gagasan kepada pihak terkait tentang perbaikan sarana meja kursi sekolah dasar yang sesuai untuk pembelajaran dengan metode active learning melalui konsep modular. Metode penelitian yang dipakai adalah kualitatif deskriptif. Lokasi penelitian terletak di Kecamatan Kedung Kabupaten Jepara Jawa Tengah, dengan sampel tiga sekolah dasar di kecamatan tersebut. Objek penelitian ini adalah desain meja kursi sekolah dasar berbasis active learning. Teknik pengumpulan data yang digunakan adalah studi pustaka, pengamatan, dan interview. Data yang telah ada dan terkumpul diuji keabsahannya dengan menggunakan teknik triangulasi. Hasil penelitian menunjukkan bahwa meja kursi kelas VI di ke-3 SD tersebut kurang representatif untuk teknik belajar active learning. Rata-rata meja dan kursi susah digerakkan untuk pembelajaran aktif. desain meja kursi dengan konsep modular menghasilkan meja kursi sesuai dengan model cluster/group $\mathrm{V}$ dan $\mathrm{U}$ yang ergonomis dan fungsional, sehingga mudah digerakkan dan menunjang sistem belajar active learning.
\end{abstract}

Kata kunci: desain, meja kursi sekolah dasar, active learning, konsep modular

\section{Pendahuluan}

Upaya perbaikan dalam dunia pendidikan telah dilakukan banyak pihak. Pemerintah secara konsisten selalu mengevaluasi dan memperbaiki berbagai sistem. Saat ini sistem pembelajaran yang gencar dilakukan adalah active learning. Sistem ini berdasarkan pada prinsip bahwa cara belajar terbaik

\footnotetext{
* Koresponden penulis e-mail : S011508006@student.uns.ac.id
} 
bagi anak-anak dengan menggunakan semua indera dan mengeksplorasi lingkungan, sehingga dalam sistem ini siswa akan lebih aktif bergerak. Active learning juga berbasis pada psikologi anak, yang memudahkan guru untuk mendekati mereka secara personal guna meningkatkan kualitas belajar. Sarana pengajaran merupakan salah satu komponen sekolah yang memiliki pengaruh cukup penting terhadap keberhasilan pendidikan, pemilihan dan perancangan alat dan sarana pengajaran secara tepat akan berdampak pada meningkatnya kualitas belajar siswa (Fuller, 1989). Senada dengan Fuller, Munandar juga menyatakan bahwa lingkungan kelas amat menentukan keberhasilan belajar, sehingga perlu adanya perubahan dari lingkungan kelas tradisional yang berpusat pada guru ke lingkungan kelas yang berpusat pada siswa (Munandar, 1993). Dengan perubahan tersebut kelas menjadi tempat yang menyenangkan dan merangsang siswa menjadi aktif, mandiri dan bertanggung jawab. Munandar juga menyatakan perubahan tersebut dapat ditempuh dengan menata meja dan kursi agar siswa leluasa belajar dan berkomunikasi.

Berbagai penelitian digunakan peneliti sebagai bahan referensi/data sekunder untuk lebih bijak dalam merumuskan solusi permasalahan meja kursi berbasis active learning. Beberapa di antaranya adalah penelitian dan perancangan tentang kursi kerja ergonomis (Suryono, 2012), tentang meja dan kursi sekolah dasar (Nurkertamanda, Saptadi, \& Herviyani, 2006; Purwaningrum, Funatsu, Xiong, Rosyidi, \& Muraki, 2015; Suprapto, 2013), tentang kursi mahasiswa (N, Halim, \& Muzammil, 2015), dan tentang mebel rotan (Saputro, 2012).

Objek penelitian ini adalah redesain meja kursi sekolah dasar berbasis active learning, sehingga peneliti membatasi ruang lingkup masalah dalam lingkup bentuk desain produk meja kursi yang relevan dengan active learning melalui konsep modular.

\section{Bahan dan Metode}

Metode penelitian yang dipakai adalah kualitatif deskriptif. Penelitian kualitatif deskriptif ini bertujuan untuk meningkatkan pemahaman tentang suatu masalah melalui pendeskripsian secara rinci dan mendalam mengenai kondisi yang sebenarnya yang terjadi di lapangan. Lokasi penelitian berada di Kecamatan Kedung Kabupaten Jepara Jawa Tengah, dengan sampel tiga sekolah dasar yaitu meja dan kursi kelas VI: SD Negeri 1 Jondang, MI Matholiul Huda Bugel dan SD Negeri III Menganti. Teknik pengumpulan data yang digunakan adalah studi pustaka, observation 'pengamatan' dan interview. Data yang telah ada dan terkumpul diuji keabsahannya dengan menggunakan teknik triangulasi. Teknik Triangulasi merupakan teknik yang membandingkan informasi atau data dengan cara yang berbeda.

Sumber data dalam penelitian ini dibagi menjadi dua yaitu sumber data primer dan sumber data sekunder. Sumber data primer merupakan semua data yang didapat dari ketiga sampel penelitian. Data Sekunder berupa buku, jurnal, dokumentasi, arsip, referensi, pustaka tentang pengembangan meja kursi dan penelitian-penelitian sebelumnya.

\section{Hasil dan Pembahasan}

Observasi yang dilakukan terhadap 3 sampel data, yaitu meja dan kursi kelas VI: di SD Negeri 1 Jondang, MI Matholiul Huda Bugel dan SD Negeri III Menganti menghasilkan beberapa temuan sebagai berikut, (1) meja dan kursi terkesan kurang nyaman bagi siswa: jenis dan bentuk kursi tidak sama, fungsi laci terlalu sempit, ukuran kursi kurang tepat bagi sebagian besar siswa, ukuran tinggi meja berbeda dan penggunaan tidak disesuaikan dengan tinggi siswa; (2) meja kursi tidak memungkinkan untuk digunakan dalam sesi pembelajaran kelompok aktif; dan (3) desain meja kursi tidak proporsional.

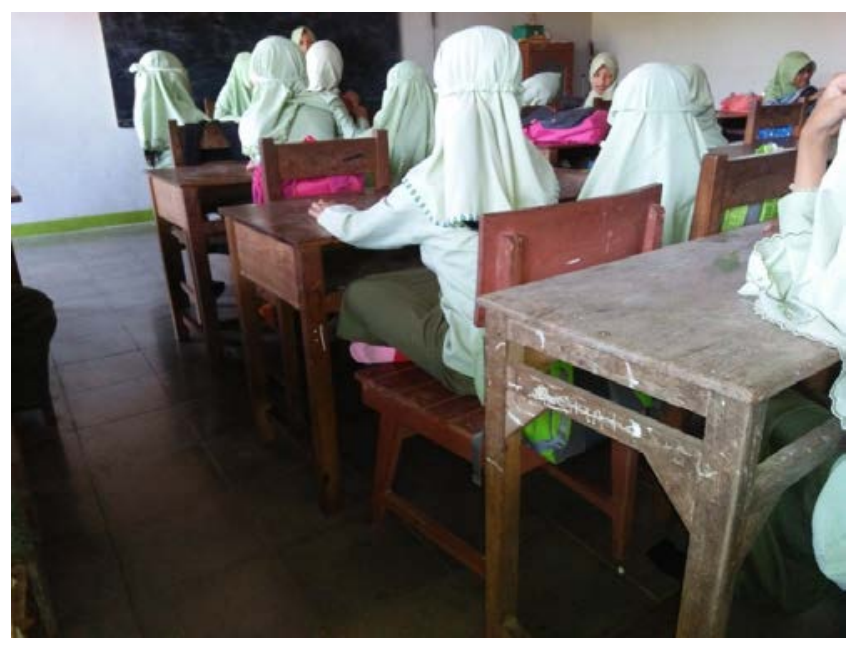

Gambar 1. meja kursi kelas VI MI Matholiul Huda Bugel

Pembelajaran kelompok aktif atau sering pula disebut sebagai metode pembelajaran aktif (active learning method) merupakan metode yang mengoptimalkan semua indera siswa demi tercapai kualitas belajar yang lebih baik. Michael Grinder menyatakan bahwa dari setiap 30 siswa, 22 diantaranya dapat belajar efektif selama gurunya 
menghadirkan kegiatan belajar yang mengkombinasikan visual, auditori dan kinestetik, guna memenuhi hal tersebut, pengajaran harus bersifat multi sensori dan penuh variasi (Grinder, 1991). Dan pendekatan kinestetik yang paling berpengaruh adalah belajar secara kelompok, menurut Abraham Maslow dengan menjadi bagian dari kelompok, siswa mendapatkan rasa aman, rasa saling memiliki (Maslow, 1968). Perasaan inilah yang memungkinkan siswa menghadapi tantangan, ketika belajar bersama kelompoknya, siswa mendapatkan dukungan emosional dan intelektual sehingga mampu melampaui ambang pengetahuan dan keterampilan.

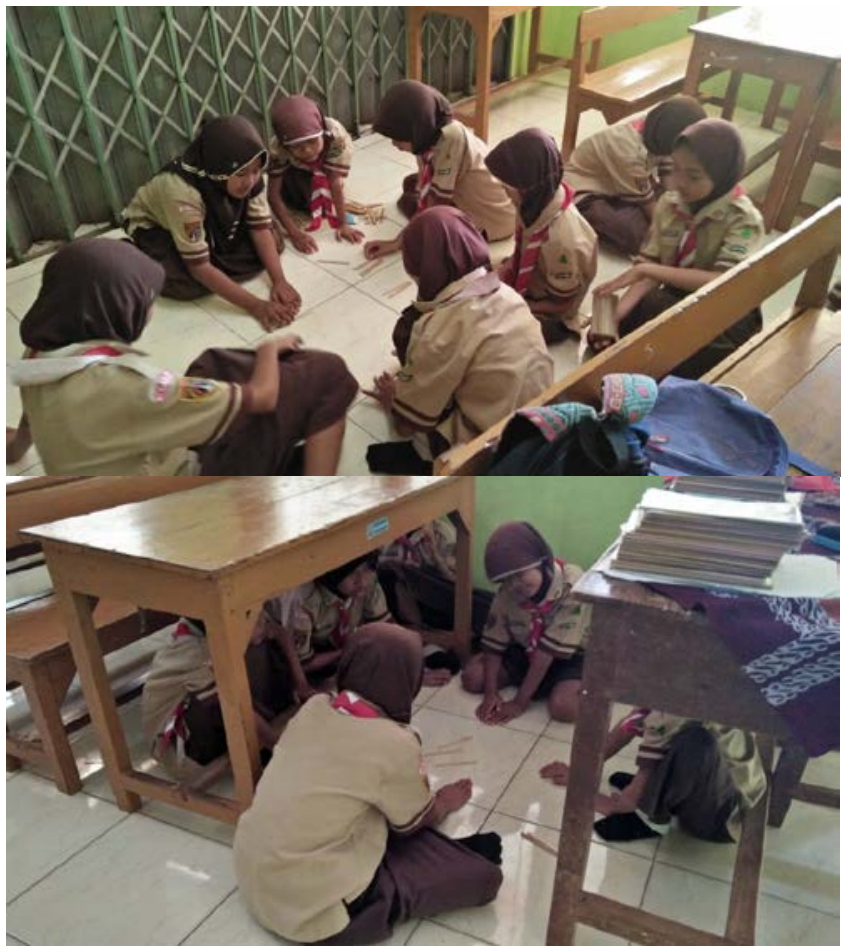

Gambar 2. Suasana belajar kelompok aktif kelas VI SDN I Jondang

Ketidakmampuan meja-kursi dalam mengakomodasi aktivitas siswa yang belajar dengan menggunakan metode active learning mendorong adanya upaya inovasi desain meja-kursi siswa tersebut. Poin pertama yang diperhatikan adalah menghindari desain kursi yang tidak ergonomis. Dari observasi sebagian besar kursi tidak ergonomis sehingga kurang nyaman dipakai. Akibat yang timbul dari pemakaian kursi yang tidak ergonomis secara terus-menerus antara lain: (1) alas kursi yang terlalu pendek akan menimbulkan tekanan pada pertengahan paha (Gambar 3); (2) alas tempat duduk yang terlalu panjang/lebar mengakibatkan adanya tekanan pada pertemuan betis dan paha atau lipatan lutut sehingga menimbulkan ketidaknyamanan (Gambar 4); (3) alas tempat duduk yang terlalu sempit menimbulkan kelelahan pada tungkai sehingga cenderung mendorong badan ke belakang yang berakibat timbulnya tekanan pada pinggang (lihat Gambar 5); (4) alas tempat duduk yang terlalu tinggi mengakibatkan tekanan pada telapak kaki seperti tampak pada Gambar 6.

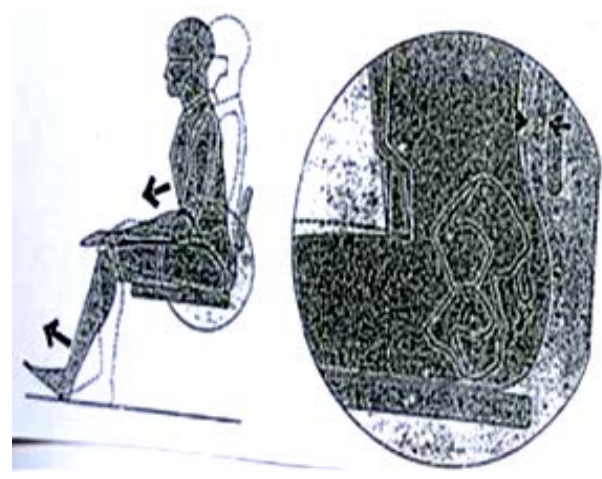

Gambar 3. Akibat alas kursi yang terlalu pendek Sumber: Human Dimension \& Interior Space (Panero \& Zelnik, 1979)
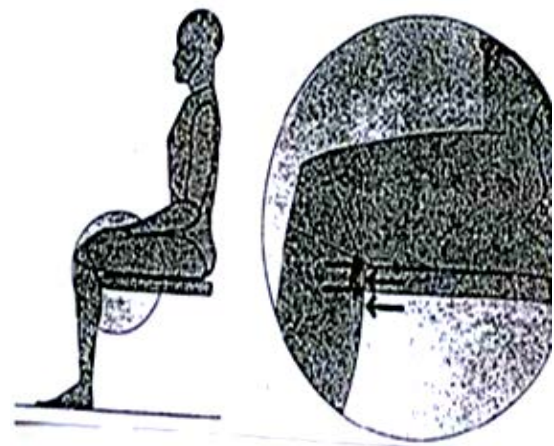

Gambar 4. Akibat alas kursi yang terlalu panjang/lebar Sumber: Human Dimension \& Interior Space (Panero \& Zelnik, 1979)
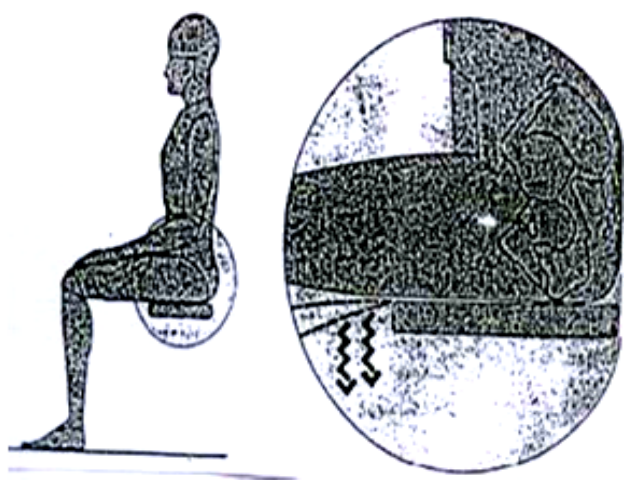

Gambar 5. Akibat alas kursi yang terlalu sempit Sumber: Human Dimension \& Interior Space (Panero \& Zelnik, 1979) 

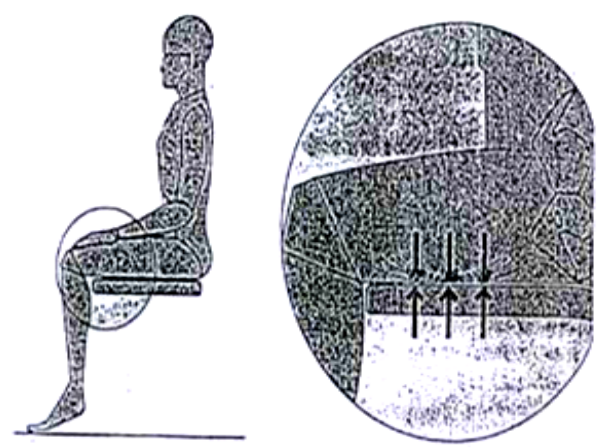

Gambar 6. Akibat Alas Kursi yang Terlalu tinggi Sumber: Human Dimension \& Interior Space (Panero \& Zelnik, 1979)

Dengan memperhatikan temuan yang berkaitan dengan ketidakergonomisan tersebut peneliti kemudian berupaya untuk memberikan alternatif desain kursi yang relevan untuk mengakomodasi aktivitas belajar yang berbasis active learning. Untuk mendesain mejanya, prinsip utama adalah mengatasi masalah ketidaknyamanan, sehingga peneliti berupaya memberikan desain yang seimbang dengan bentuk kursi dan nyaman. Tahap awal untuk memulai pendesainan adalah mengukur tinggi badan masingmasing siswa (Gambar 7). Sedangkan untuk pertimbangan berat badan siswa peneliti menggunakan standar yang dikemukakan oleh Harpenden Caliper (Pauweni, 2009).

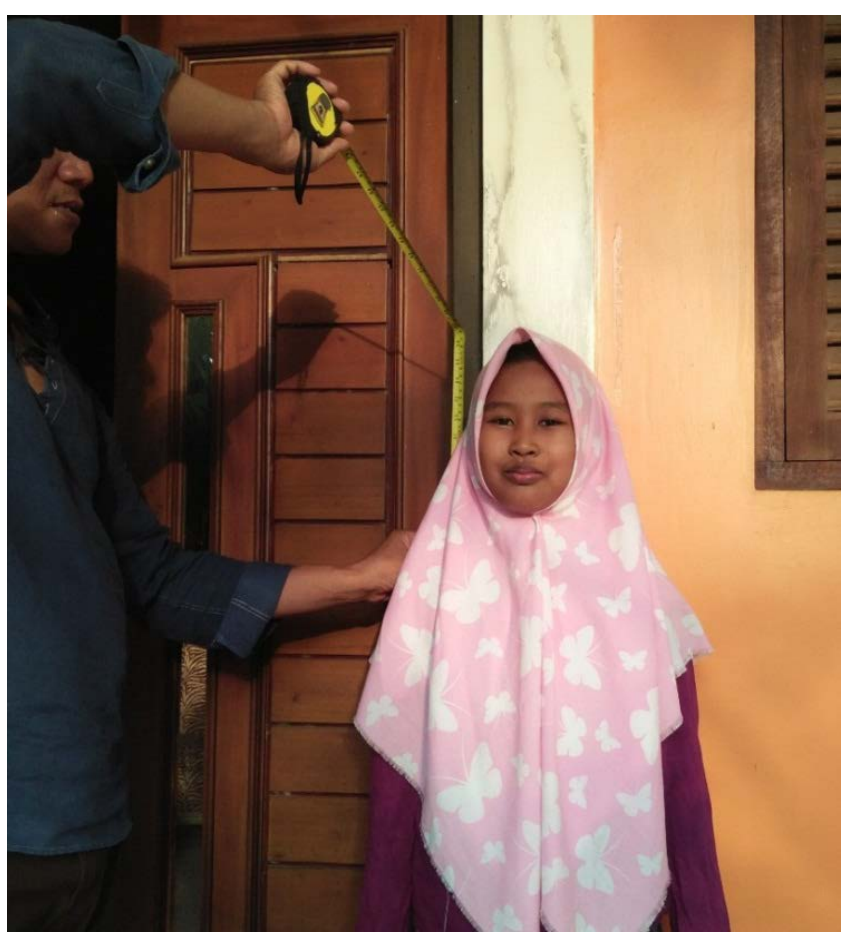

Gambar 7. Peneliti mengukur tinggi siswa
Berdasarkan analisis di atas, maka desain meja dan kursi yang sesuai adalah desain yang menganut sistem modular. Definisi modular atau modularitas dalam desain adalah pendekatan desain yang membagi sistem menjadi bagian-bagian kecil yang disebut modul, yang bersifat mandiri dan kemudian digunakan dalam sistem yang berbeda. Menurut Muharam, arti dari kata modular adalah memiliki kemampuan untuk dipindahkan dengan mudah dan umumnya berdiri sendiri dalam bentuk modul yang dapat dipisah-pisahkan (Muharram, 2009).

Tujuan utama perancangan meja dan kursi tersebut terutama adalah untuk memudahkan siswa melakukan proses pembelajaran active learning dengan melakukan berbagai kegiatan berdiskusi, yang mengubah model kelas tradisional ke kelas belajar aktif. Prinsip kerja sistem modular adalah membagi sistem menjadi modul, yang bersifat mandiri dan kemudian digunakan dalam sistem yang berbeda.

Pada penelitian ini peneliti membagi modul meja dan kursi, diuraikan dan kemudian dipilih bagian mana yang kurang tepat desainnya. Data-data hasil observasi dan data pustaka dianalisis untuk menentukan titik temu diantara keduanya. Bagian desain yang tidak tepat tersebut dicarikan solusi desain terbaik.

Tabel 1. Karakteristik meja-kursi siswa

\begin{tabular}{ll}
\hline Meja & Kursi \\
\hline $\begin{array}{l}\text { Ringan } \\
\text { Kuat dan Mampu menahan } \\
\text { Teban }\end{array}$ & $\begin{array}{l}\text { Ringan } \\
\text { Kuat dan Mampu menahan } \\
\text { beban }\end{array}$ \\
$\begin{array}{l}\text { Mudah dipindahkan } \\
\text { dengan mendorong }\end{array}$ & Mudah dipindahkan \\
$\begin{array}{l}\text { Dimensi meja sesuai } \\
\text { dengan antropometri }\end{array}$ & $\begin{array}{l}\text { Dimensi kursi sesuai } \\
\text { Terdapat tempat }\end{array}$ \\
$\begin{array}{l}\text { penyimpanan buku dan } \\
\text { alat tulis }\end{array}$ & \\
$\begin{array}{l}\text { Bisa disusun menjadi } \\
\text { bentuk lain }\end{array}$ & $\begin{array}{l}\text { Bisa disusun menjadi } \\
\text { Packaging yang compact } \\
\text { dengan kursi } \\
\text { Memudahkan di proses } \\
\text { produksi dengan bentuk } \\
\text { kantilever }\end{array}$ \\
\hline
\end{tabular}

Faktor-faktor yang menjadi pertimbangan dalam proses perancangan dan realisasi desain meja kursi ini berkaitan dengan lingkungan alam dan sosial, budaya, estetis, ekonomi, fungsi maupun teknik. Faktor-faktor tersebut secara signifikan berpengaruh terhadap unsur visual meja kursi, terlihat dari aspek bahan, konstruksi, ukuran, bentuk dan warna. Langkah- 
langkah penelitian yang dilakukan dalam penyusunan konsep desain meja dan kursi menghasilkan dua kategori yaitu ergonomis dan fungsional yang sesuai dengan model cluster/group $\mathrm{V}$ dan U. Sehingga kualitas meja kursi yang dihasilkan tampak pada Tabel 1.

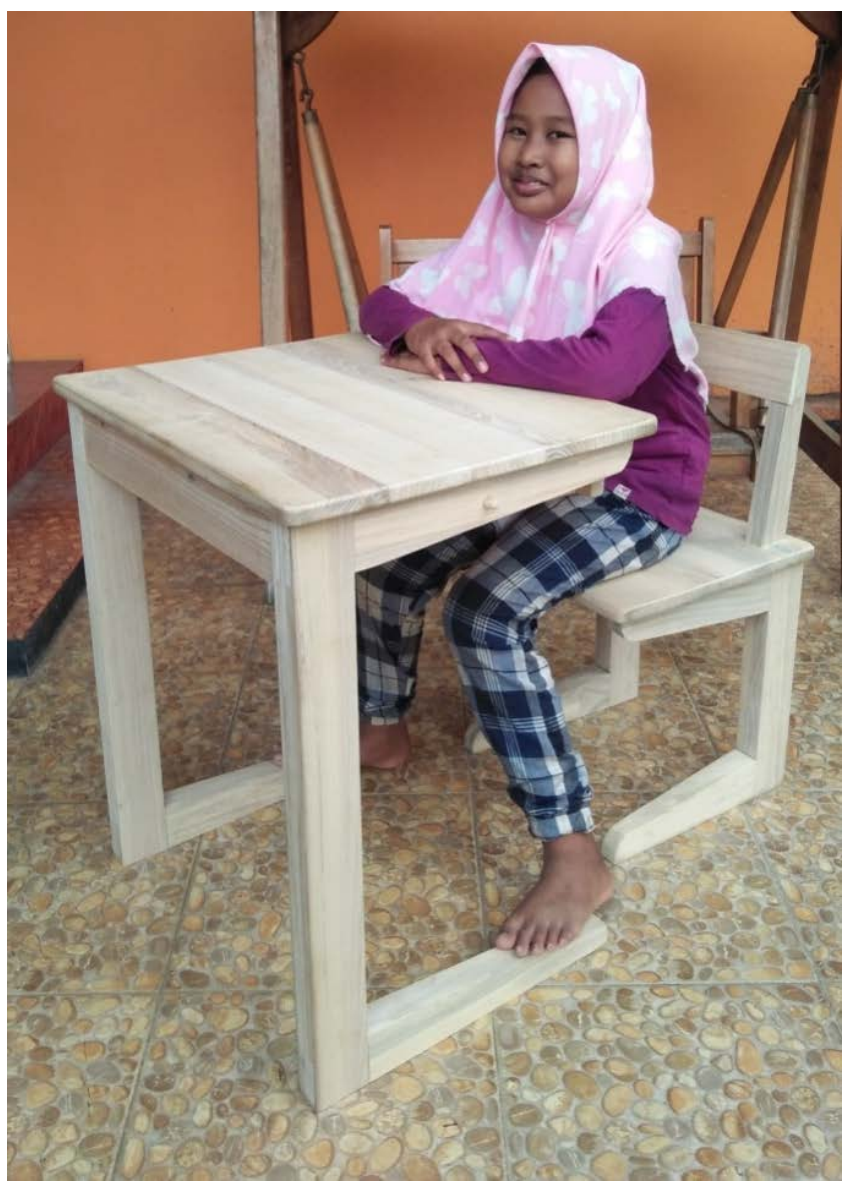

Gambar 8. Meja kursi berbasis active learning dengan konsep modular

Gambar 8 memperlihatkan prototipe meja dan kursi siswa sekolah dasar yang dihasilkan dari inovasi desain meja-kursi dengan menerapkan sistem modular. Adanya meja-kursi yang ergonomis dan fungsional tersebut diyakini mampu mengatasi masalah-masalah yang terpetakan sebelumnya, sehingga pembelajaran active learning dapat berlangsung lebih baik dan maksimal.

Finishing mebel melibatkan bahan khusus yang menggunakan pengencer air, sehingga aman bagi anak-anak. Untuk warna finishing, dipilih warna alami kayu, seperti coklat muda, coklat tua, atau finishing transparan yang menonjolkan warna kayu itu sendiri. Finishing pada meja kursi yang seperti itu diharapkan akan membangkitkan kehangatan dan keakraban sehingga mampu menghadirkan suasana natural. Dengan demikian guru lebih mudah mengaplikasikan metode active learning dan siswa lebih nyaman dalam belajar.

\section{Kesimpulan}

Hasil penelitian menunjukkan bahwa meja kursi kelas VI SD Negeri 1 Jondang, MI Matholiul Huda Bugel dan SD Negeri III Menganti kurang representatif untuk teknik belajar active learning. Rata-rata meja dan kursi susah digerakkan untuk pembelajaran aktif. Desain meja kursi dengan konsep modular menghasilkan meja kursi sesuai dengan model cluster/group $\mathrm{V}$ dan $\mathrm{U}$ yang ergonomis dan fungsional, sehingga mudah digerakkan dan menunjang sistem belajar active learning.

\section{Daftar pustaka}

Fuller, R. (1989). Probiotics in man and animals. Journal of Applied Bacteriology, 66(5), 365-378. https://doi.org/10.1111/j.1365-2672.1989.tb05105.x

Grinder, M. (1991). Righting the educational conveyor belt. Portland: Metamorphous Press.

Maslow, A. H. (1968). Some educational implications of the humanistic psychologies. Harvard Educational Review, 38(4), 685-696.

https://doi.org/10.17763/haer.38.4.j07288786v86w660

Muharram, A. N. (2009). Menata Furnitur di Ruang Sempit. Jakarta: Griya Kreasi.

Munandar, S. C. U. (1993). Mengembangkan bakat dan kreativitas anak sekolah: petunjuk bagi para guru dan orang tua. Jakarta: Gramedia.

N, R. M., Halim, L., \& Muzammil, R. (2015). Program Kreativitas Mahasiswa (Karsa Cipta), Perancangan Kursi Mahasiswa “UNION.” Jakarta.

Nurkertamanda, D., Saptadi, S., \& Herviyani, D. D. (2006). Perancangan meja dan kursi anak menggunakan metode Quality Function Deployment (QFD) dengan pendekatan Athropometri dan bentuk fisik anak. J@TI UNDIP : Jurnal Teknik Industri, 1(1). Retrieved from https://ejournal.undip.ac.id/index.php/jgti/article/view/2196

Panero, J., \& Zelnik, M. (1979). Human Dimension \& Interior Space: A Source Book of Design Reference Standards. New York: Whitney Library of Design.

Pauweni, M. (2009). Mengevaluasi Komposisi Tubuh. Semarang.

Purwaningrum, L., Funatsu, K., Xiong, J., Rosyidi, C. N., \& Muraki, S. (2015). Effect of Furniture Weight on Carrying, Lifting, and Turning of Chairs and Desks among Elementary School Children. PLoS ONE, 10(6), e0128843. https://doi.org/10.1371/journal.pone.0128843

Saputro, F. W. (2012). Perancangan Kursi dan Meja Ruang Tamu Berbasis Kearifan Lokal dengan Metode Kansei Engineering dalam Upaya Peningkatan Nilai Ekonomis Produk Rotan di Desa Trangsan. Universitas Muhammadiyah Surakarta, Surakarta.

Suprapto. (2013). Perancangan meja-kursi yang adjustable bagi anak sekolah dasar. Techno Science, 5(2), 715-722. 
Productum Vol 3 No 3 Januari-Juni 2018 pp. 107-112

Suryono, E. (2012). Rancangan Kursi Kerja Berbasis Ergonomi Untuk Mengurangi Kelelahan Pada Pekerja Pelinting Rokok Di Pt Djitoe Indonesia Tobacco Tahun 2012. Surakarta: Universitas Muhammadiyah Surakarta. 